\title{
Enfermagem em cirurgia plástica: uma especialização a se desenvolver no Brasil
}

\author{
Luciana Secches de Freitas, D.Sc.
}

Minha formação em Odontologia e em Enfermagem, com mestrado e doutorado em enfermagem e atuação como enfermeira junto ao Departamento Otorrinolaringologia e Cirurgia de Cabeça e Pescoço, permitiram-me desenvolver competências (conhecimentos, habilidades, atitudes, valores e emoçóes) na assistência a pacientes submetidos a cirurgias estéticas e reparadoras de cabeça e pescoço.

Nos últimos anos venho atuando como dentista e enfermeira, desenvolvendo ações administrativas e assistenciais na atenção a pacientes atendidos em clínica de cirurgia plástica. As atividades que desempenho envolvem toda a rotina da clínica, como recepção e orientação aos pacientes e familiares, instrumentação no intraoperatório, supervisionando $o$ atendimento de enfermagem prestado durante a internação hospitalar, realizando pesquisas de satisfação, estatísticas de atendimentos, dimensionando e priorizando as necessidades, orientando os pacientes no pré e pós-operatório e também realizando os curativos, remoção de drenos, enfim, diferentes procedimentos relacionados à atuaçáo do enfermeiro no contexto da cirurgia plástica.

A Cirurgia Plástica é uma especialidade ampla, destinada a reparar, reconstruir e substituir deformidades envolvendo a pele, o sistema musculoesquelético, estruturas craniomaxilofaciais, extremidades, mama, tronco e genitália externa. É divulgada nos diferentes meios de comunicação e no âmbito científico a excelência que o Brasil vem alcançando na cirurgia plástica. No entanto, apesar do grande desenvolvimento da cirurgia plástica na medicina brasileira, esta área é pouco explorada na formação do enfermeiro, seja em nível de graduação como de pós-graduação lato sensu.

Atuando como enfermeira no contexto da cirurgia plástica, tenho verificado que esta é uma área de atuaçáo incipiente do enfermeiro. Nestes 10 anos, observei que surgiram e foram desenvolvidas e aprimoradas muitas técnicas cirúrgicas, assim como procedimentos estéticos e cosméticos, deixando visível um campo de atuaçáo para o enfermeiro.

Deve ser destacado que é o profissional da área de saúde não médico com condições de atuar técnica e cientificamente em todas as fases relacionadas à cirurgia plástica, prestando atendimento a pacientes nos períodos pré, intra e pós-operatório. Então, é urgente que seja qualificado em cursos de pós-graduação lato sensu, particularmente em nível de especialização, na área de cirurgia plástica.

Atualmente sou a primeira enfermeira do Brasil a fazer parte da Sociedade Americana de Enfermagem em Cirurgia Plástica (American Society of Plastic Surgery Nurse- ASPSN), sociedade que oferece aos seus membros o livre acesso a informaçáo e a troca de informaçóes nesta área, permitindo atualizar e aprimorar meus conhecimentos para exercer minhas funçóes como enfermeira na área de cirurgia plástica.

Tive, também, a oportunidade de verificar o papel desenvolvido pelas enfermeiras americanas, deixando evidente que os enfermeiros brasileiros têm muito a aprender no contexto da cirurgia plástica. Ficou evidente que, apesar de o Brasil ocupar a $2^{\circ}$ posição no ranking de cirurgias plásticas, os enfermeiros norte-americanos fazem diversos procedimentos como: aplicação de toxina botulínica, aplicaçáo de ácidos, manipulando aparelhos de lasers. Também trabalham com o desenvolvimento da qualidade, pesquisa, educação e possuem uma entidade de classe atuante, desenvolvendo grandes congressos e simpósios para discussão e prestígio da especialidade de Cirurgia Plástica.

No Brasil, as competências e valorização dos enfermeiros já são evidentes em várias áreas e especialidades, como no caso da Obstetrícia, Cardiologia, Pediatria e muitas outras. Porém, no que diz respeito à cirurgia plástica a trajetória está apenas começando. Por isso, desejo contribuir na Jornada pela Especialização em Enfermagem em Cirurgia Plástica no Brasil. 